\title{
Application of the Taguchi's Loss Function in the Breeding of Nile Tilapia Fed with Different Levels of Alcohol Yeast
}

\author{
Vandir Medri ${ }^{1 *}$, Geni Varéa Pereira ${ }^{2}$ and Júlio Hermann Leonhardt ${ }^{3}$ \\ ${ }^{1}$ Departamento de Matemática Aplicada, Universidade Estadual de Londrina, Campus Universitário, 86051-990, \\ Londrina, PR. ${ }^{2}$ Departamento de Bioquímica, Universidade Estadual de Londrina, Campus Universitário, 86051- \\ 990, Londrina, PR. ${ }^{3}$ Departamento de Biologia Animal e Vegetal, Universidade Estadual de Londrina, Campus \\ Universitário, 86051-990, Londrina, PR - Brasil.
}

\begin{abstract}
Studies were conducted to evaluate the effect of 10\%, 20\% and 30\% ration substitutions for distillery yeast on the function Taguchi's loss using two hundred and forty 45-day-old fingerlings of Nile tilapia (Oreochromis niloticus), sexually reverted with an initial average weight of $1.25 \pm 0.14 \mathrm{~g}$ placed in amianthus box.. The average results obtained for the limnological parameters of the water quality control through chemical analysis were considered normal. Taguchi's losses for the total production, for the dead and discarded fishes did not show correlation for the different levels of alcohol yeast inclusion, showing that the choice of the yeast level in the ration for these fishes depended on its availability and occasional cost. It was observed that the losses, specially those in the amianthus boxes, could be attributed to the density limitation, absence of natural feeding and great dispersion in the fishe size.
\end{abstract}

Key words: quality, ration, Taguchi, tilapia, yeast.

\section{INTRODUCTION}

Yeast, the by-product of alcoholic fermentation, could be an important alternative of protein on formulation of animal ration, so that high levels of protein, carbohydrates, lipids, etereo extract, vitamins and minerals are obtained (Mattos, 1984). The first report on the use of yeast in fish breeding was by Tunison et al., (1942). Alves (1988), write waking on trout breeding to determinate its needs of thiamin, riboflavin and nicotinic acid, reported that gills diseases caused by nutritive deficiency could be reduced by adding dried yeast in the fish diet. According to NAS-NRC, (1993), the substitution of the conventional ingredients is advisable to lower the diet costs, however, it is necessary to be informed about the biologic worth of this products. Tilapias are able to utilize the remains of agroindustry such as yeast, besides the possibility to assimilate carbohydrates contained in the vegetable ration ingredients. Young tilapia eat mainly zooplancton and phitoplancton; while the adults, accept a variety of artificial food, vegetables, larvae and insects (Castagnolli, 1992; Wu et al., 1995).
The Taguchi's loss function or the quality function is defined as the value of the monetary loss expected, caused by the characteristic deviation of performance, relating to the wished value or a specific value. This concept of loss shows a new thought of investments in quality improvement, because in a competitive economy, the continuos improvement of the quality and the reduction of costs are necessary to keep the product in market (Kackar, 1986). The loss considered here are calculated in monetary values and are associated to quantifiable characteristics of the product.

Taguchi et al. (1990), hipothesised that the probabilistic distribution of the values obtained from a large scale production is normal and not uniform, so it follows the reduced function of Gauss. They considered as loss for the society the difference between the nominal values $\mathrm{m}$ and the obtained values $\mathrm{x}$, in a simplified case where the quality depends on only one dimension. In general cases, where the quality depends on many dimensions, the loss function is applied to each dimension and the value of

\footnotetext{
* Author for correspondence
} 
one loss is summed to the others individual losses. In other words each unity causes a loss, which is not kept to the owner, but is distributed to all the society (Stange, 1996, mentioned by Medri,1997). The value of the monetary loss caused by the quality decrease could be refated with the removal of the nominal value $(\mathrm{m})$ of the specification. It was shown to be a quadratic function. The maximum value was obtained when the deviation exceeded the specification limits (Taguchi et al., 1990; Guedes, 1996). When the loss function grows symmetrically with the deviation of the functional characteristics round the normal value, "the nominal is the best one". Phadke (1989), extended this concept to other two special cases of functional characteristics of quality: "The smaller is the best one" and "the biggest is the best one".

The objective this study was to verify if there was correlation of the Taguchi's loss function for the total production, for the dead and rejected fishes and the between four rations isoproteic balanced $(28 \% \mathrm{~PB})$ and isocaloric balanced $(2933 \mathrm{Kcal} / \mathrm{Kg})$ with $\mathrm{T}_{1}=0 \%$ (standard group), $\mathrm{T}_{2}=10 \%, \mathrm{~T}_{3}=20 \%$ and $\mathrm{T}^{4}=30 \%$ (tested groups) of yeast from alcoholic distillery exceeding.

\section{MATERIALS AND METHODS}

Two hundred and forty fingerlings of Nile tilapia (Oreochromis niloticus), ceded by the Fish Breeding Station of the Animal and Vegetal Department of Biology of the Biological Science Center of the Universidade Estadual de Londrina, mesured the initial average weight and length of the fingerlings were $1.25 \pm 0,14 \mathrm{~g}$ and $3.84 \pm 0.17 \mathrm{~cm}$ respectively. The fishes were reverted by the supply of rations with $60 \mathrm{mg} / \mathrm{kg}$ of diet of the male hormone $17 \alpha-$ metiltestosterone during a period of 30 days. A computational program was utilized to elaborate the ration BRUN10 with the needs of the mentioned species. The four isoproteic (28\% PB) and isocaloric balanced rations $(2933 \mathrm{Kcal} / \mathrm{kg}$ ) with 0 (control group), 10,20 and 30\% (tested groups) of yeast from alcoholic distillery exceeding are shown in Table 1.

Table 1. Composition of the experimental rations for the Nile tilapia.

\begin{tabular}{|c|c|c|c|c|}
\hline Ingredients (\%) & Standard $\left(\mathrm{T}_{1}\right)$ & Test $\left(\mathrm{T}_{2}\right)$ & Test $\left(\mathrm{T}_{3}\right)$ & Test $\left(\mathrm{T}_{4}\right)$ \\
\hline Yeast & 0.00 & 10.00 & 20.00 & 30.00 \\
\hline Ration & 100.00 & 90.00 & 80.00 & 70.00 \\
\hline Total & 100.00 & 100.00 & 100.00 & 100.00 \\
\hline \multicolumn{5}{|l|}{ Ration Formulation (\%) } \\
\hline Yeast & 0.00 & 10.00 & 20.00 & 30.00 \\
\hline Fish flour & 27.00 & 25.00 & 23.00 & 15.00 \\
\hline Wheat flour & 13.00 & 15.00 & 17.00 & 15.00 \\
\hline Crushed maize & 47.30 & 41.01 & 35.31 & 30.11 \\
\hline Soybean flour & 11.05 & 7.75 & 3.99 & 9.89 \\
\hline Vegetable oil & 1.65 & 1.24 & 0.70 & --- \\
\hline Total & 100.00 & 100.00 & 100.00 & 100.00 \\
\hline \multicolumn{5}{|l|}{ Ration nutrients (\%) } \\
\hline Dry matter & 87.86 & 87.86 & 88.90 & 89.24 \\
\hline Crude protein & 28.00 & 28.00 & 28.00 & 28.00 \\
\hline Methabolicable energy (kcal/kg) & 2933.00 & 2933.00 & 2933.00 & 2933.00 \\
\hline Calcium $(\mathrm{Ca})$ & 1.54 & 1.55 & 1.34 & 0.97 \\
\hline Phosphorus (P) & 1.15 & 1.14 & 1.13 & 0.97 \\
\hline
\end{tabular}

The fingerlings were randomly distributed in 12 groups of 20 individuals, each group was placed in an amianthus box with capacity of $500 \mathrm{l}$, with continuos aeration and water exchange. They were supplied with water from a semi-artesian well, with discharge of 6liters/second/hectare and placed in a closed environment. The boxes were siphoned weekly to remove residues and algae deposited on the bottom and on the walls. The fishes were daily observed in case of any 
uncommon behaviour, morphological variation and death. The experimental period was 330 days $(15 / 03 / 95$ to $15 / 02 / 96)$.

Using a paquimeter and a balance of precision, the total weight (Wt), in grams, and the total length of the fishes (Lt), in centimeters, were monthly measured. The water temperature was checked every day with a mercury thermometer. Monthly, the alkalinity was measured through the addition method, the dissolved oxygen through Winkler method, ammonia through photometer method of Berthelot, nitrite through Griess-Hosvay, total phosphorus and dissolvable phosphorus through Murphy and $\mathrm{pH}$ through potentiometer. The methodology used to test these parameters was according to Lind (1979) and Standard Methods (1980). Each treatment named (T) was given to three groups of fishes (triplicate). The fingerlings were daily fed according to Wilson (1991).

The functional characteristic of quality it was used: "the biggest one is the best". In this case, the best value was not defined, the bigger was the characteristic value (fish weight) the better it was. The loss caused by a fish that has passed the inferior limit of tolerance was represented by $\mathrm{A}$, and its corresponding deviation was $\Delta \mathrm{A}$. The function was expressed by:

$\mathrm{L}(\mathrm{Y})=\mathrm{K}\left[1 / \mathrm{Y}^{2}\right]=\mathrm{A} \Delta^{2} \mathrm{v}^{2}($ Phadke, 1989).

\section{Calculus of cost of each fish}

$$
\begin{aligned}
& \mathrm{P} 1=\text { ration }+ \text { yeast }+ \text { fingerling }+ \text { population }+ \text { biometry }+ \text { medicines }+\ldots+\text { disfishery } \\
& \mathrm{P} 2=\text { ration }+ \text { yeast }+ \text { fingerling }+ \text { population }+ \text { biometry }+ \text { medicines }+\ldots+\text { disfishery } \\
& \ldots=\ldots+\ldots+\ldots+\ldots+\ldots+\ldots+\ldots+\ldots+\ldots+\ldots+\ldots+\ldots+\ldots+\text { disfishery }
\end{aligned}
$$

$\sum_{1}^{k} \mathrm{P}_{\mathrm{i}}=\sum_{1}^{k}($ ration + yeast + fingerling + population + biometry + medicines $+\ldots+$ disfishery $)$

A calculus; $A=\frac{1}{k} \cdot \sum_{i=1}^{k} P_{i}$ com $\mathrm{i}=1,2, \ldots, \mathrm{k}$

where $\mathrm{k}$ is the number of fishes and $\mathrm{A}$ is the loss caused by fishes that passed the inferior limit of tolerance.

The fish production that presented high dispersion would have a higher cost on account to the rejects and consequently bigger quality

$\mathrm{v}^{2}$ calculus;

$\mathrm{v}^{2}=\frac{1}{n} \cdot\left(\frac{1}{y_{1}^{2}}+\frac{1}{y_{2}^{2}}+\ldots+\frac{1}{y_{n}^{2}}\right)=\frac{1}{n} \cdot \sum_{i=1}^{n}\left(\frac{1}{y_{i}^{2}}\right)$

where, $v^{2}$ is the quadratic average deviation and $y_{i}$ is the value of the studied characteristic (weigh). loss. In this case, it was better to divide the fishes in lots to calculate the tolerance and the reduction of losses. In general, the procedure to calculate the tolerance $(\Delta)$ is: $\Delta=$ average of fishes / 2 . 
Table 2. Length and average weigh of fishes on treatments $T_{1}, T_{2}, T_{3}$ and $T_{4}$.

\begin{tabular}{lcccccccc}
\hline & \multicolumn{3}{c}{ Length $(\mathrm{cm})$} \\
\hline Months & $\mathrm{T}_{1}=0$ & $\mathrm{~T}_{2}=10$ & $\mathrm{~T}_{3}=20$ & $\mathrm{~T}_{4}=30$ & $\mathrm{~T}_{1}=0$ & $\mathrm{~T}_{2}=10$ & $\mathrm{~T}_{3}=20$ & $\mathrm{~T}_{4}=30$ \\
\hline 0 & 3.75 & 3.75 & 3.73 & 3.93 & 1.29 & 1.31 & 1.16 & 1.36 \\
1 & 5.43 & 5.61 & 5.88 & 6.39 & 3.45 & 4.32 & 4.15 & 5.05 \\
2 & 6.25 & 6.57 & 7.02 & 8.038 & 5.98 & 7.91 & 7.37 & 10.68 \\
3 & 6.94 & 7.64 & 7.46 & 8.86 & 7.92 & 11.14 & 9.14 & 14.08 \\
4 & 7.81 & 8.56 & 8.66 & 9.91 & 11.29 & 15.42 & 13.56 & 19.85 \\
5 & 9.141 & 9.83 & 9.74 & 11.05 & 17.41 & 22.71 & 19.43 & 27.32 \\
6 & 10.67 & 11.12 & 11.11 & 12.33 & 30.14 & 36.03 & 31.90 & 43.86 \\
7 & 11.78 & 12.13 & 12.30 & 13.18 & 44.10 & 49.15 & 45.17 & 57.06 \\
8 & 13.38 & 13.36 & 13.70 & 14.60 & 64.60 & 69.84 & 68.13 & 79.16 \\
9 & 15.23 & 14.40 & 15.56 & 15.86 & 90.19 & 81.37 & 99.28 & 102.32 \\
10 & 17.22 & 16.65 & 17.09 & 17.61 & 116.75 & 113.75 & 115.75 & 122.43 \\
11 & 18.28 & 17.40 & 18.09 & 18.69 & 154.18 & 139.35 & 151.29 & 161.65 \\
\hline
\end{tabular}

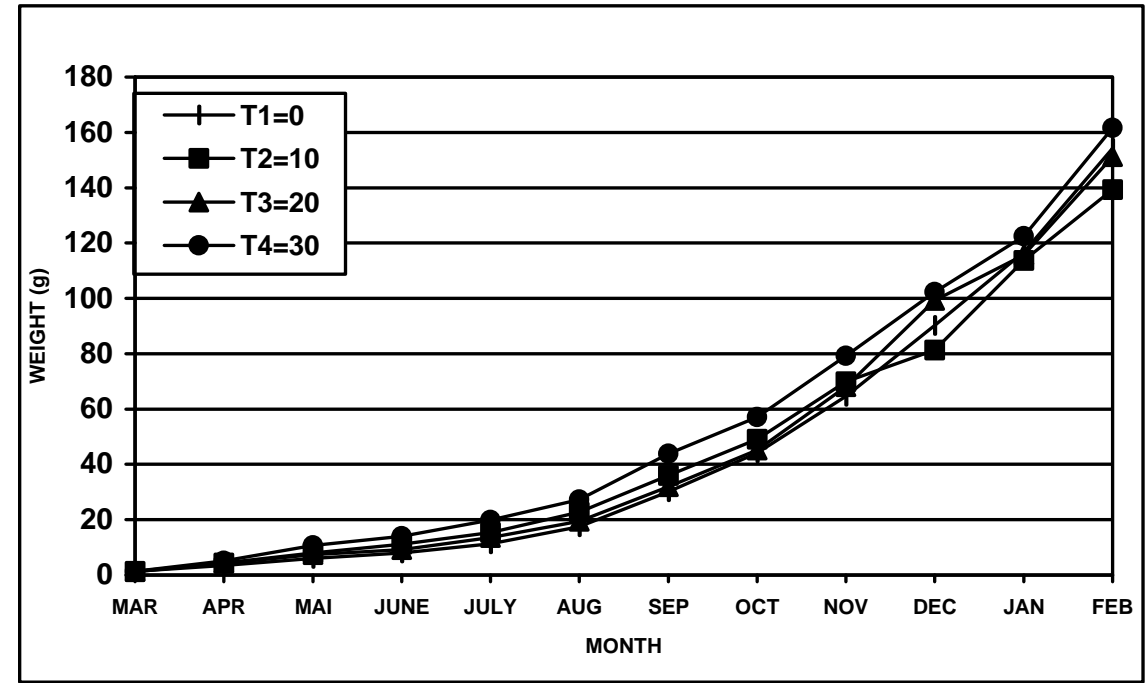

Figure 1. Average weight of the fishes (g).

\section{RESULTS AND DISCUSSION}

The results of length and total average weight of the standard group $\left(T_{1}\right)$ and the tested groups $\left(\mathrm{T}_{2}, \mathrm{~T}_{3}\right.$ and $\left.\mathrm{T}_{4}\right)$ of tilapias are shown in the Table 2 and Figure 1.

Data of literature demonstrate low index of growth, length and weight in the amianthus box during the experimental period. This could be associated to the absence of natural feeding, besides the little space per fish that did not follow the population density limits. This, according to Coda (1996), has great influence on the growth index of the fishes.
The most important variables that must be controlled in fish breeding, are temperature, alkalinity, dissolved oxygen, ammonia, nitrite, phosphorus and $\mathrm{pH}$ (Boyd, 1990). The average values obtained for the physical and chemical variables were in the zone considered ideal for fish breeding, according to Tavares (1994). The rate of water change was kept high during the experimental period, so that the values obtained for the physico-chemical variables of the water did not represent significant statistic difference $(\mathrm{P}<0,05)$ among the treatments $\mathrm{T}_{1}, \mathrm{~T}_{2}, \mathrm{~T}_{3}$ and $\mathrm{T}_{4}$.

The Tables 3, 4, 5, 6 and Figure 2 present the Taguchi's loss in the treatment $\mathrm{T}_{1}, \mathrm{~T}_{2}, \mathrm{~T}_{3}$ and $\mathrm{T}_{4}$ for the cost of production. 
Table 3. Cost of production ( $T_{1}=0 \%$ of Yeast).

\begin{tabular}{lccc}
\hline Specification & Quantity & Unitary cost ( R \$) & Total ( R \$) \\
\hline Ration & $24.180 \mathrm{~kg}$ & 0.30 & 7.250 \\
Yeast & $0.000 \mathrm{~kg}$ & 0.23 & 0.000 \\
Fingerling & 60 & 0.04 & 2.400 \\
Population & $0.250 \mathrm{~h}$ & 1.00 & 0.250 \\
Biometry & $2.750 \mathrm{~h}$ & 1.00 & 2.750 \\
Food supplied & $5.500 \mathrm{~h}$ & 1.00 & 5.500 \\
Medicines & $\ldots$ & 5.00 & 1.250 \\
Disfishery & $0.1250 \mathrm{~h}$ & 1.00 & 0.125 \\
Total & $\ldots$ & $\ldots$ & 19.525 \\
\hline
\end{tabular}

$\underline{\text { A Calculus }}$

1/42(0.025455831)

$$
\mathrm{A}=\sum_{1}^{k} \mathrm{P}_{\mathrm{i}} / \mathrm{k}=19.525 / 60=\underline{0.3254}
$$

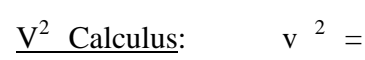

Calculus of the Taguchi's

$\underline{\text { loss function (L) }}$

$\Delta$ Calculus

1/42(0.025455831)

$\Delta=\mathrm{m} / 2=154.19 / 2=\underline{77.095}$

$\underline{70.33}$.

$\mathrm{L}=\mathrm{A} \Delta^{2} \mathrm{v}^{2}=0.3254(77.095)^{2}$

$\mathrm{L}=\underline{1.17222}, \quad \log 0, \quad 60 \times 1.17222=\mathrm{R} \$$

Table 4. Cost of production $\left(\mathrm{T}_{2}=10 \%\right.$ of Yeast $)$.

\begin{tabular}{lccc}
\hline Specification & Quantity & Unitary cost ( R \$) & Total ( R \$) \\
\hline Ration & $21.390 \mathrm{~kg}$ & 0.30 & 6.420 \\
Yeast & $2.380 \mathrm{~kg}$ & 0.23 & 0.550 \\
Fingerling & 60 & 0.04 & 2.400 \\
Population & $0.250 \mathrm{~h}$ & 1.00 & 0.250 \\
Biometry & $2.750 \mathrm{~h}$ & 1.00 & 2.750 \\
Food supplied & $5.500 \mathrm{~h}$ & 1.00 & 5.500 \\
Medicines & $\ldots$ & 5.00 & 1.250 \\
Disfishery & $0.125 \mathrm{~h}$ & 1.00 & 0.125 \\
Total & $\ldots$ & $\ldots$ & 19.245 \\
\hline
\end{tabular}

$\underline{\text { A Calculus }}$

1/41(0.012242089)

$$
\mathrm{A}=\sum_{1}^{k} \mathrm{P}_{\mathrm{i}} / \mathrm{k}=19.245 / 60=\underline{0.3208}
$$

$\underline{\mathrm{V}^{2} \text { Calculus: }} \quad \mathrm{v}^{2}=$

Calculus of the Taguchi's

$\underline{\text { loss function }(\mathrm{L})}$

$\triangle$ Calculus

1/41(0.012242089)

$\Delta=\mathrm{m} / 2=139.35 / 2=\underline{69.675} \mathrm{~g}$

$\underline{27.90}$

\author{
$\mathrm{L}=\mathrm{A} \Delta^{2} \mathrm{v}^{2}=0.3208(69.675)^{2}$ \\ $\mathrm{L}=\underline{0.46501}, \quad \log 0, \quad 60 \times 0.46501=\mathrm{R} \$$
}


Table 5 . Cost of production $\left(\mathrm{T}_{3}=20 \%\right.$ of Yeast).

\begin{tabular}{lccc}
\hline Specification & Quantity & Unitary cost ( R \$ & Total ( R\$) \\
\hline Ration & $19.790 \mathrm{~kg}$ & 0.30 & 5.940 \\
Yeast & $4.950 \mathrm{~kg}$ & 0.23 & 1.140 \\
Fingerling & 60 & 0.04 & 2.400 \\
Population & $0.250 \mathrm{~h}$ & 1.00 & 0.250 \\
Biometry & $2.750 \mathrm{~h}$ & 1.00 & 2.750 \\
Food supplied & 5.500 & 1.00 & 5.500 \\
Medicines & $\ldots$ & 5.00 & 1.250 \\
Disfishery & $0.125 \mathrm{~h}$ & 1.00 & 0.125 \\
Total & $\ldots$ & $\ldots$ & 19.355 \\
\hline A Calculus & & & $\mathrm{V}^{2}$ Calculus:
\end{tabular}

loss function (L)

\begin{tabular}{lr}
$\underline{\Delta \text { Calculus }}$ & $\mathrm{L}=\mathrm{A} \Delta^{2} \mathrm{v}^{2}=0.3226(75.645)^{2}$ \\
\hline $1 / 44(0.047722599)$ & $\mathrm{L}=\underline{2.00215}, \quad \log , \quad 60 \times 2.00215=\mathrm{R} \$$
\end{tabular}

$\underline{120.13 .}$.

Table 6. Cost of production $\left(\mathrm{T}_{4}=30 \%\right.$ of Yeast).

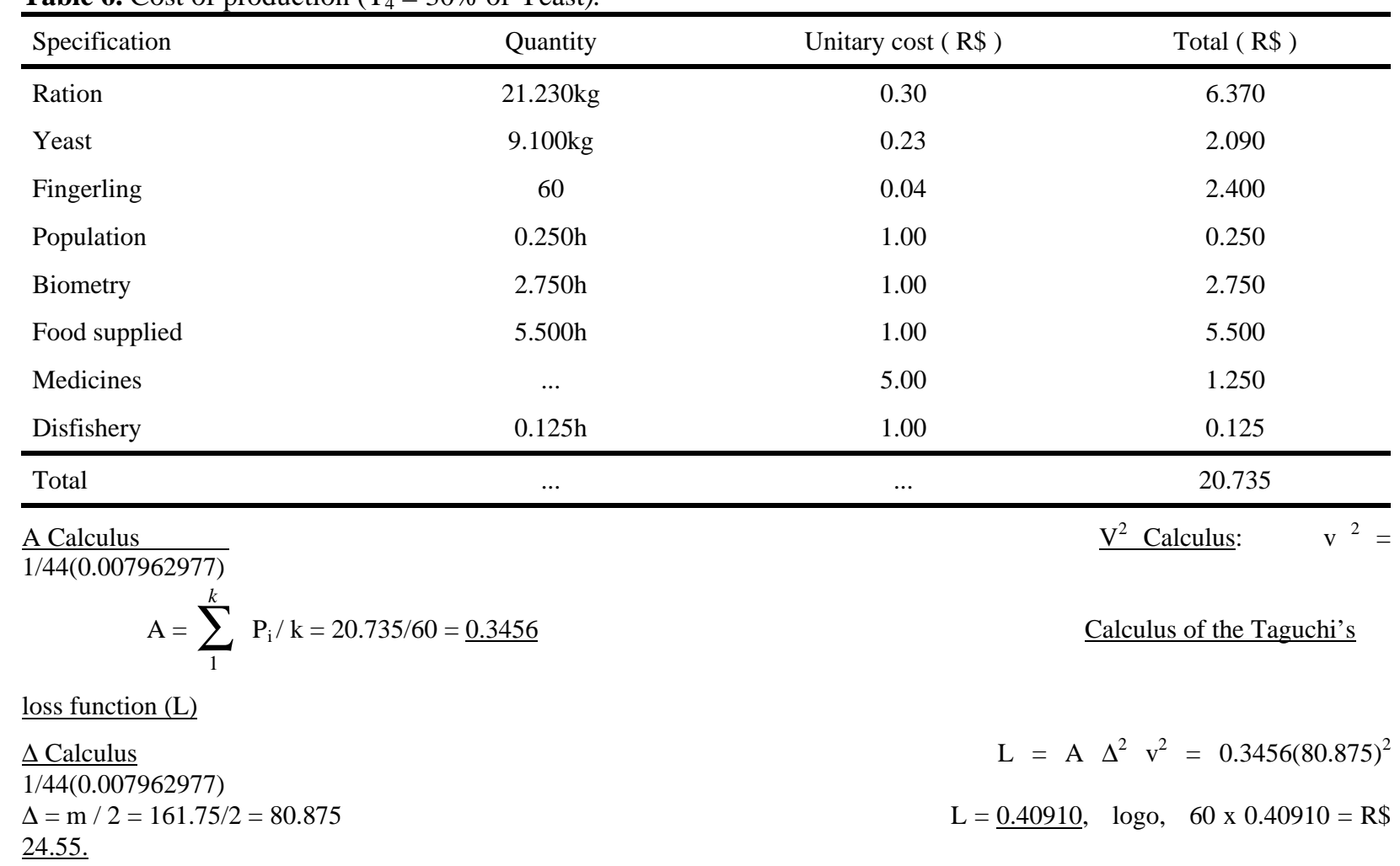




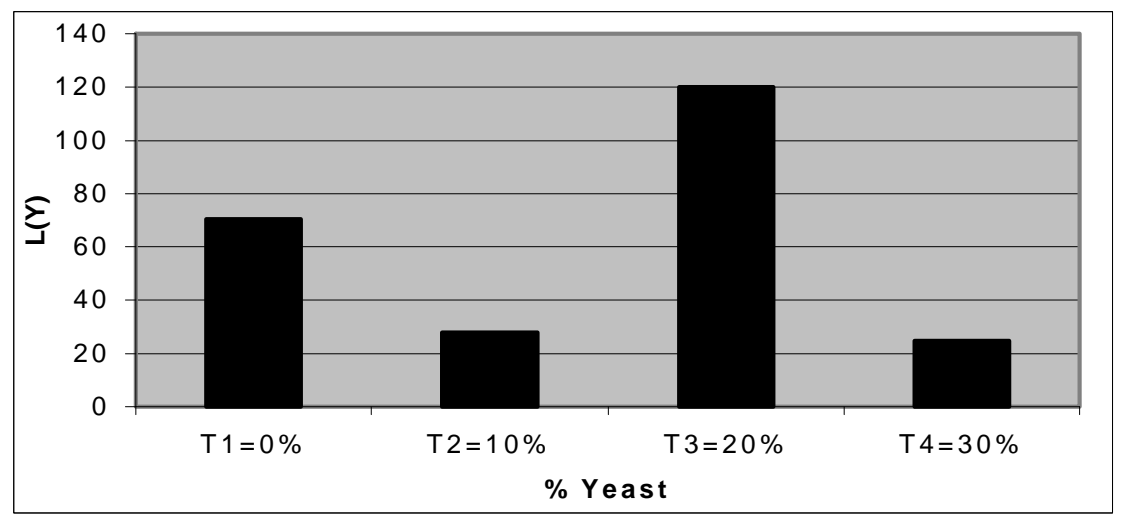

Figure 2. Taguchi's loss function for the fishes prodution.

The Taguchi's loss function for the fish production in amianthus box showed that the treatment which included $\mathrm{T}_{4}=30 \%$ of yeast in ration (Figure 2) resulted in an inferior production cost comparing to the others treatments. For the treatments $\mathrm{T}_{1}=0 \%, \mathrm{~T}_{2}=10 \%$, $\mathrm{T}_{3}=20 \%$ and $\mathrm{T}_{4}=30 \%$ of distillery yeast in ration, the losses were, $\mathrm{R} \$ 70.33,27.90,120.13$,
24.55 respectively. These results confirmed the possibility of using this residues as partial substitute of fish ration.

The Tables 7, 8, 9, 10 and Figure 3 present the Taguchi's loss in the treatment $T_{1}, T_{2}, T_{3}$ and $T_{4}$ for the dead fishes.

Table 7. Dead fishes $\left(\mathrm{T}_{1}=0 \%\right.$ of Yeast $)-\mathrm{k}=18$.

\begin{tabular}{lccc}
\hline Specification & Quantity & Unitary cost ( R\$) & Total ( R \$) \\
\hline Ration & $4.458 \mathrm{~kg}$ & 0.30 & 1.340 \\
Yeast & $0.000 \mathrm{~kg}$ & 0.23 & 0.000 \\
Fingerling & 18 & 0.04 & 0.720 \\
Population & $0.070 \mathrm{~h}$ & 1.00 & 0.070 \\
Biometry & $0.830 \mathrm{~h}$ & 1.00 & 0.830 \\
Food supplied & $1.650 \mathrm{~h}$ & 1.00 & 1.650 \\
Medicines & $\ldots$ & 5.00 & 0.370 \\
Disfishery & $0.040 \mathrm{~h}$ & 1.00 & 0.040 \\
\hline Total & $\ldots$ & $\ldots$ & 5.020 \\
\hline
\end{tabular}

$\underline{\text { A Calculus }}$

$1 / 42(0.025455831)$

$$
\mathrm{A}=\sum_{1}^{k} \mathrm{P}_{\mathrm{i}} / \mathrm{k}=5.02 / 18=\underline{0.2789}
$$

$\underline{\text { loss function }(\mathrm{L})}$

\section{$\triangle$ Calculus}

$1 / 42(0.025455831)$

$\Delta=\mathrm{m} / 2=154.19 / 2=\underline{77.095}$

18.08 .
V ${ }^{2}$ Calculus: $\quad \mathrm{v}^{2}=$

Calculus of the Taguchi's 
Table 8. Dead fishes $\left(\mathrm{T}_{2}=10 \%\right.$ of Yeast $)-\mathrm{k}=19$.

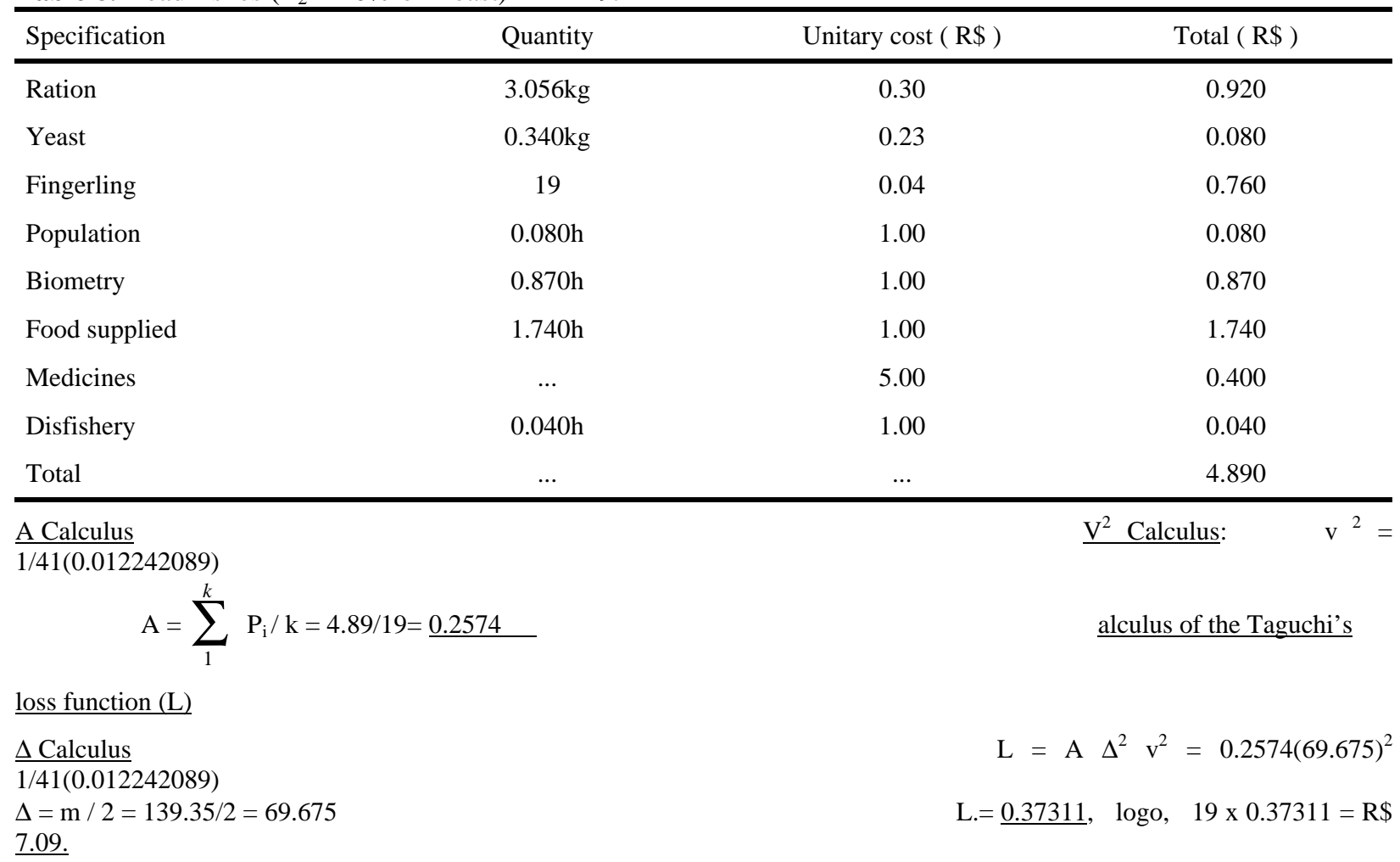

Table 9. Dead fishes $\left(\mathrm{T}_{3}=20 \%\right.$ of Yeast $)-\mathrm{k}=16$.

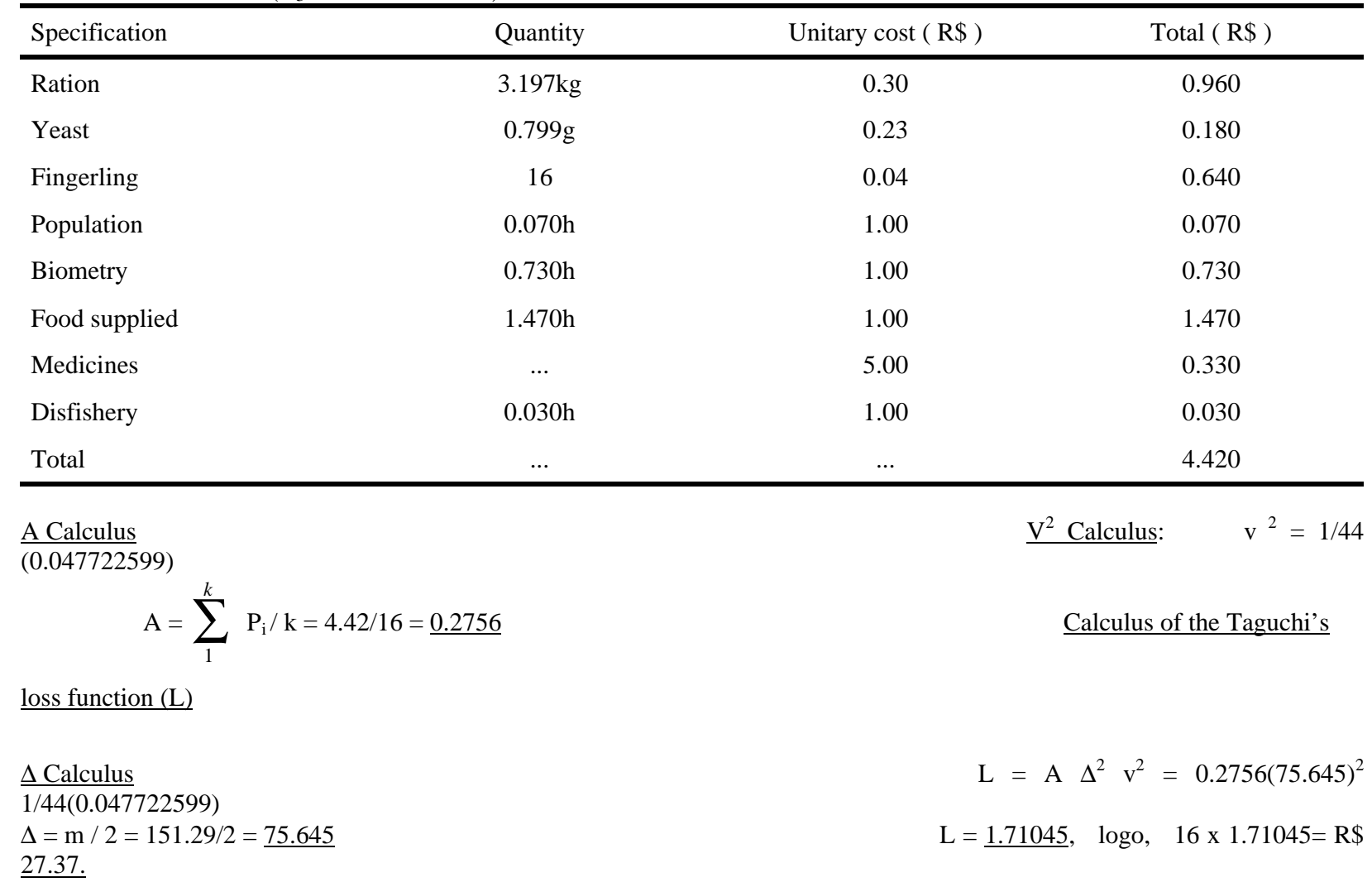


Table 10. Dead fishes $\left(T_{4}=30 \%\right.$ of Yeast $)-k=16$.

\begin{tabular}{lccc}
\hline Specification & Quantity & Unitary cost ( R\$) & Total ( R \$) \\
\hline Ration & $4.948 \mathrm{~kg}$ & 0.30 & 1.480 \\
Yeast & $2.120 \mathrm{~kg}$ & 0.23 & 0.490 \\
Fingerling & 16 & 0.04 & 0.640 \\
Population & $0.070 \mathrm{~h}$ & 1.00 & 0.070 \\
Biometry & $0.730 \mathrm{~h}$ & 1.00 & 0.730 \\
Food supplied & $1.470 \mathrm{~h}$ & 5.00 & 1.470 \\
Medicines & $\ldots$ & 0.33 & 0.330 \\
Disfishery & $0.030 \mathrm{~h}$ & 1.00 & 0.030 \\
Total & $\ldots$ & $\ldots$ & 5.240 \\
\hline
\end{tabular}

A Calculus

1/44(0.007962977)

$$
\mathrm{A}=\sum_{1}^{k} \mathrm{P}_{\mathrm{i}} / \mathrm{k}=5.24 / 16=\underline{0.3275}
$$

loss function (L)

\section{$\triangle$ Calculus}

1/44(0.007962977)

$\Delta=\mathrm{m} / 2=161.75 / 2=\underline{80.875}$

$\underline{6.20 .}$

The treatments $\mathrm{T}_{2}$ and $\mathrm{T}_{4}$, that included $10 \%$ and $30 \%$ of distillery yeast in ration (Figure 3), resulted in losses of $\mathrm{R} \$ 7.09$ and 6.06
$\mathrm{V}^{2}$ Calculus:

$\mathrm{v}^{2}=$

Calculus of the Taguchi's

$$
\begin{gathered}
\mathrm{L}=\mathrm{A} \quad \Delta^{2} \mathrm{v}^{2}=0.3275(80.875)^{2} \\
\mathrm{~L}=\underline{0.38754,}, \log 0, \quad 16 \times 0.38754=\mathrm{R} \$
\end{gathered}
$$

respectively, less than the standard group $\left(\mathrm{T}_{1}=0 \%\right)$, which lost $\mathrm{R} \$ 18.08$ on account to the dead fishes in the amianthus boxes.

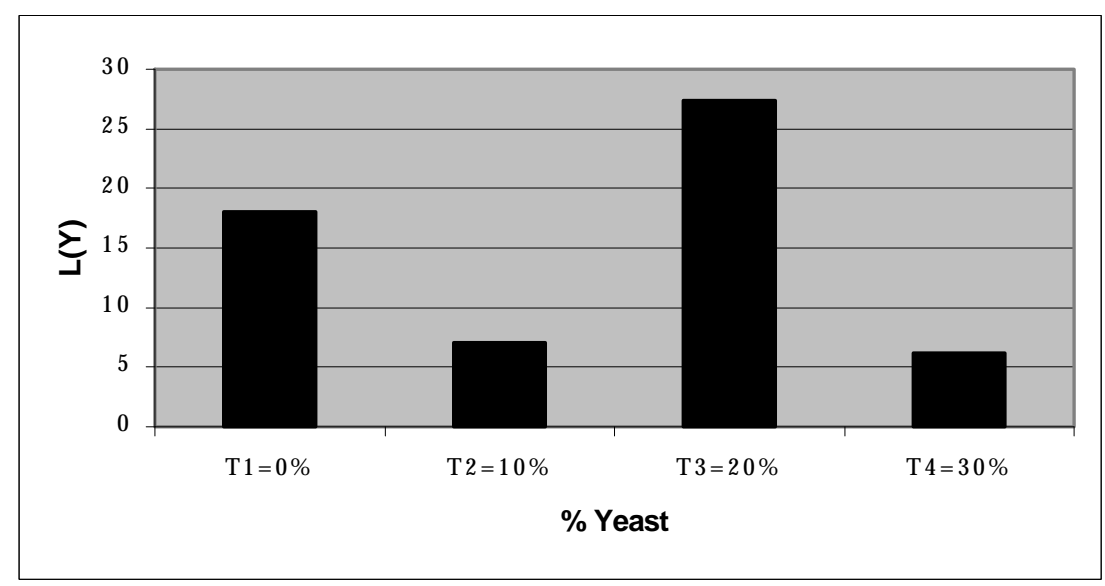

Figure 3. Taguchi's loss for the dead fishes.

The Tables 11, 12, 13, 14 and Figure 4 present the Taguchi's loss in the treatment $\mathrm{T}_{1}, \mathrm{~T}_{2}, \mathrm{~T}_{3}$ and $\mathrm{T}_{4}$ for the discarded fishes. 
Table 11. Discarded fishes $\left(T_{1}=0 \%\right.$ of Yeast $)-k=9$.

\begin{tabular}{lccc}
\hline Specification & Quantity & Unitary cost ( R\$) & Total ( R \$) \\
\hline Ration & $5.180 \mathrm{~kg}$ & 0.30 & 1.550 \\
Yeast & $0.000 \mathrm{~kg}$ & 0.23 & 0.000 \\
Fingerling & 9 & 0.04 & 0.360 \\
Population & $0.040 \mathrm{~h}$ & 1.00 & 0.040 \\
Biometry & $0.410 \mathrm{~h}$ & 1.00 & 0.410 \\
Food supplied & $0.820 \mathrm{~h}$ & 1.00 & 0.820 \\
Medicines & $\ldots$ & 5.00 & 0.190 \\
Disfishery & $0.020 \mathrm{~h}$ & 1.00 & 0.020 \\
Total & $\ldots$ & $\ldots$ & 3.390 \\
\hline A Calculus & & & $\mathrm{V}^{2}$ Calculus:
\end{tabular}

loss function (L)

$\triangle$ Calculus

$1 / 42(0.025455831)$

$\Delta=\mathrm{m} / 2=154.19 / 2=\underline{77.095}$

$\underline{12.21}$.
$\mathrm{L}=\mathrm{A} \Delta^{2} \mathrm{v}^{2}=0.3767(77.095)^{2}$

$\mathrm{L}=\underline{1.35702}, \quad \log 0, \quad 9 \mathrm{x} 1.35702=\mathrm{R} \$$

Table 12. Discarded fishes $\left(\mathrm{T}_{2}=10 \%\right.$ of Yeast $)-\mathrm{k}=15$.

\begin{tabular}{lccc}
\hline Specification & Quantity & Unitary cost ( R\$) & Total ( R\$) \\
\hline Ration & $7.830 \mathrm{~kg}$ & 0.30 & 2.350 \\
Yeast & $0.870 \mathrm{~kg}$ & 0.23 & 0.020 \\
Fingerling & 15 & 0.04 & 0.600 \\
Population & $0.060 \mathrm{~h}$ & 1.00 & 0.060 \\
Biometry & $0.690 \mathrm{~h}$ & 1.00 & 0.690 \\
Food supplied & $1.380 \mathrm{~h}$ & 1.00 & 1.380 \\
Medicines & $\ldots$ & 5.00 & 0.310 \\
Disfishery & $0.030 \mathrm{~h}$ & 1.00 & 0.030 \\
Total & $\ldots$ & $\ldots$ & 5.620 \\
\hline
\end{tabular}

$\underline{\text { A Calculus }}$ 1/41(0.012242089)

$$
\mathrm{A}=\sum_{1}^{k} \mathrm{P}_{\mathrm{i}} / \mathrm{k}=5.62 / 15=\underline{0.3747}
$$

$\underline{\text { loss function }(\mathrm{L})}$

$\Delta$ Calculus 1/41(0.012242089)

$\Delta=\mathrm{m} / 2=139.35 / 2=\underline{69.675}$

$\underline{8.15}$.

\author{
$\underline{\mathrm{V}^{2} \text { Calculus: }} \quad \mathrm{v}^{2}=$ \\ Calculus of the Taguchi's \\ $\mathrm{L}=\mathrm{A} \Delta^{2} \mathrm{v}^{2}=0.3747(69.675)^{2}$ \\ $\mathrm{L}=\underline{0.54314}, \quad \log 0, \quad 15 \times 0.54314=\mathrm{R} \$$
}


Table 13. Discarded fishes $\left(T_{3}=20 \%\right.$ of Yeast $)-k=12$.

\begin{tabular}{|c|c|c|c|}
\hline Specification & Quantity & Unitary cost ( $\mathrm{R} \$$ ) & Total ( R\$ ) \\
\hline Ration & $5.400 \mathrm{~kg}$ & 0.30 & 1.620 \\
\hline Yeast & $1.350 \mathrm{~g}$ & 0.23 & 0.310 \\
\hline Fingerling & 12 & 0.04 & 0.480 \\
\hline Population & $0.050 \mathrm{~h}$ & 1.00 & 0.050 \\
\hline Biometry & $0.550 \mathrm{~h}$ & 1.00 & 0.550 \\
\hline Food supplied & $1.100 \mathrm{~h}$ & 1.00 & 1.100 \\
\hline Medicines & $\ldots$ & 5.00 & 0.250 \\
\hline Disfishery & $0.030 \mathrm{~h}$ & 1.00 & 0.030 \\
\hline Total & $\ldots$ & $\ldots$ & 4.390 \\
\hline $\begin{array}{l}\frac{\text { A Calculus }}{1 / 44(0.047722599)} \\
\qquad \mathrm{A}=\sum^{k}\end{array}$ & & & 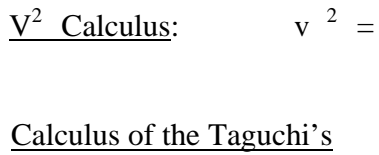 \\
\hline
\end{tabular}

loss function (L)

$\triangle$ Calculus

1/44(0.047722599)

$\Delta=\mathrm{m} / 2=151.29 / 2=75.645$

$\underline{27.24}$.

Table 14. Discarded fishes $\left(\mathrm{T}_{4}=30 \%\right.$ of Yeast $)-\mathrm{k}=10$.

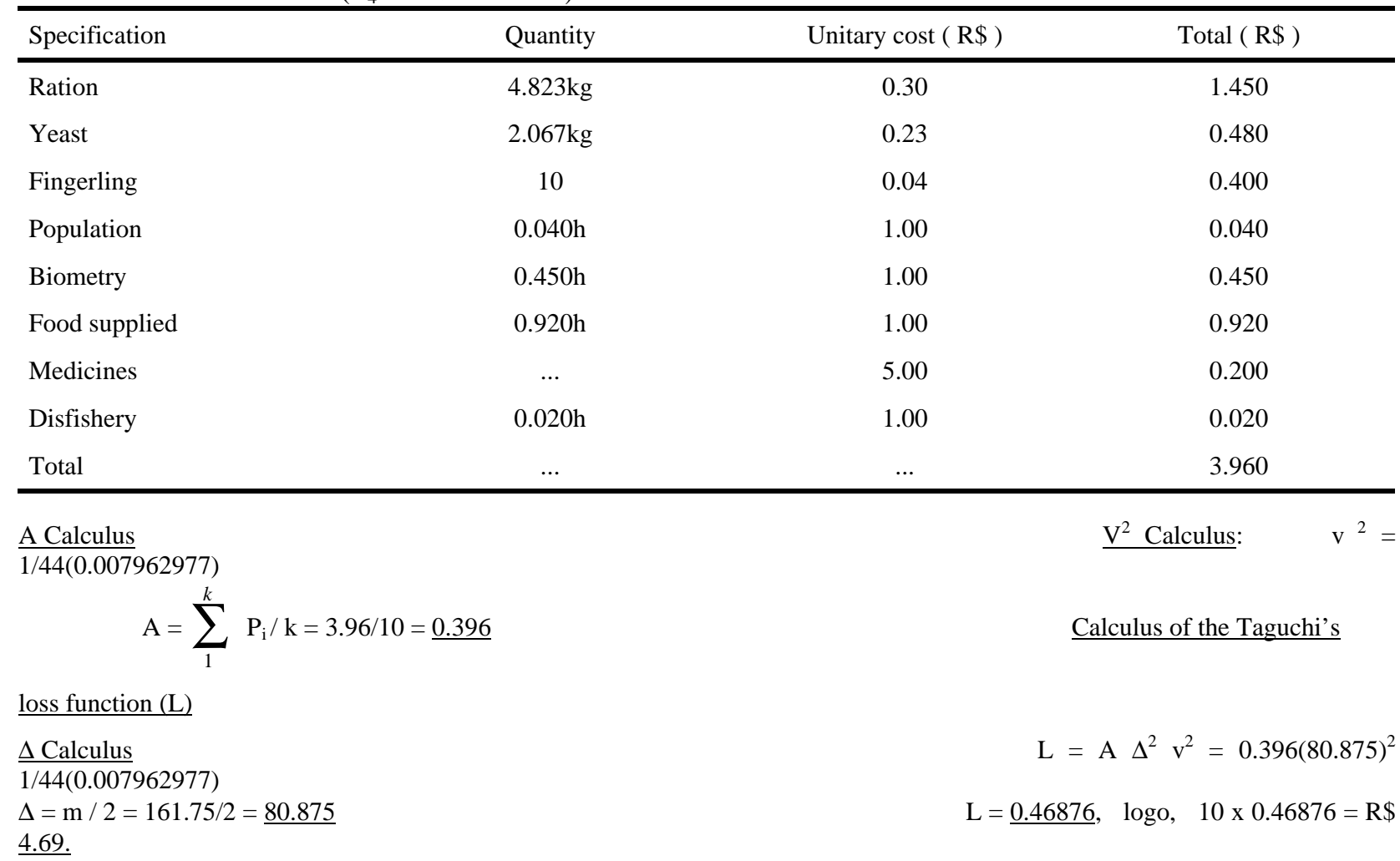

$\mathrm{L}=\mathrm{A} \Delta^{2} \mathrm{v}^{2}=0.3658(75.645)^{2}$

$\mathrm{L}=\underline{2.27026}, \quad \operatorname{logo}, \quad 12 \times 2.27026=\mathrm{R} \$$ 


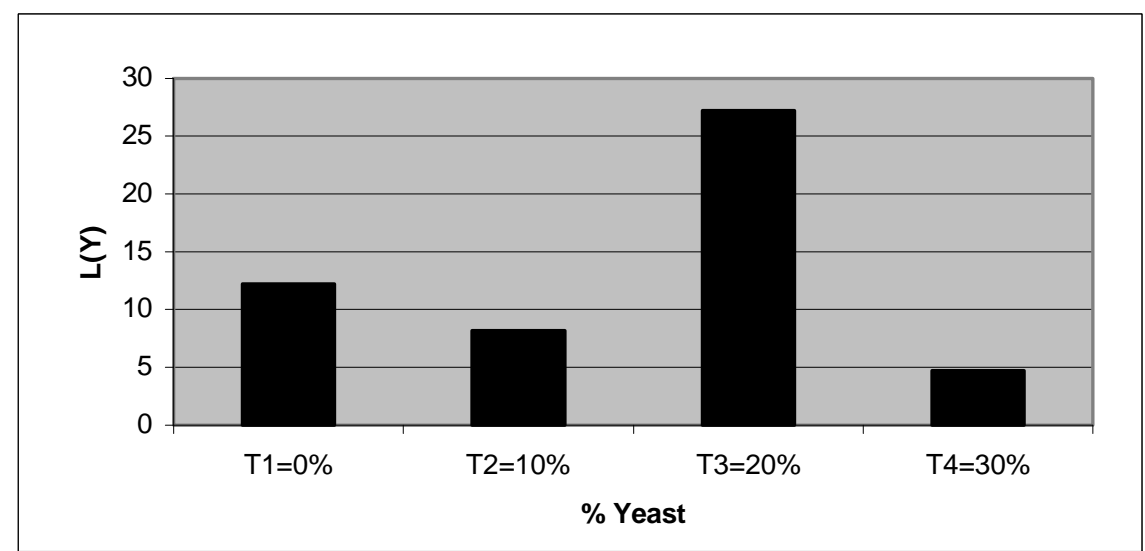

Figure 4. Taguchi's loss for the Discarded fishes.

There were no positive correlation among Tagushi's loss for the total production, dead and Discarded fishes and the four balanced rations in all the experiments, which meat that the increasing inclusion of distillery yeast in tilapia ration depended only on its availability and occasional cost. The losses in the amianthus boxes could be attributed to the density limitation, absence of natural feeding and big dispersion of the fish size.

\section{RESUMO}

Foram utilizados 240 alevinos de tilápia do nilo (Oreochromis niloticus) com 45 dias, sexualmente revertidas com peso médio inicial de $1.25 \pm 0.14 \mathrm{~g}$ alocados em caixas de amianto. Foi avaliado o efeito da substituição de $10 \%$, $20 \%$ e $30 \%$ de ração por levedura de destilaria sobre a função perda de Taguchi. Os resultados médios obtidos nos parâmetros limnológicos para o controle da qualidade da água através da análise química foram normais. As perdas de Taguchi para a produção total, para os peixes mortos e descartados não revelou uma correlação para os diferentes níveis de inclusão de levedura alcooleira, indicando que a escolha do nível de levedura na ração para estes peixes depende da sua disponibilidade e custo ocasional. Observou-se que perdas acentuadas nas caixas de amianto podem ser atribuídas ao limite de densidade, ausência de alimentação natural e grande dispersão no tamanho dos peixes.

\section{REFERENCES}

Alves, L. M. C. G.; Pezzato, L. E.; Neto, A. C. G.; Pezzato, A. C.; Barros, M. M.; \& Padovani, C. R. (1988), Avaliação de níveis crescentes de levedura seca de vinhaça incorporadas às rações de tilápia do Nilo. In: SIMÓSIO LATINOAMERICANO DE AQÜICULTURA, $6, \quad$ SIMPÓSIO BRASILEIRO DE AQÜICULTURA, 5, 1988. Florianópolis, Resumos... Florianópolis: Abra, pp. 355-361.

Boyd, C. E. (1990), Water quality in ponds for aquaculture. Birmingham: Alabama Agricultural Experiment Station, 477p.

Castagnolli, N. (1992), Piscicultura de água doce. Jaboticabal: FUNEP, 189p.

Coda, S. (1996), Efeito da densidade de estocagem no cultivo intensivo de tilápia do nilo, Oreochromis niloticus. In: SIMPÓSIO BRASILEIRO DE AQÜICULTURA, 9, Sete Lagoas, Mg. 1996, p.131. Resumos... Sete Lagoas, Simbraq.

Guedes, T. A. (1996), Procedimentos de otimização no planejamento e controle da qualidade de produtos e processos. Florianópolis, 140p. Tese (Doutorado em Engenharia de Produção). Universidade Federal de Santa Catarina.

Kackar, R. N. (1986), Taguchi's quality philosophy: analysis and commentary. Quality progress, 19(12), 19-29.

Lind, O. T. (1979), Handbook of common methods in limnology. London: Ed. Mosby Company, pp. 59-85.

Mattos, W. R. S, Dantas D'arce, R. \& Machado, P. F. (1984), O uso de levedura da 
fermentação alcoólica na alimentação de ruminantes. Informe Agropecuário, Belo horizonte, 10(119), 56-60.

Medri, V. (1997), Técnicas estatísticas e de engenharia da qualidade para avaliar o desempenho de diferentes níveis de levedura na criação de tilápia (Oreochromis niloticus). Florianópolis, 180p. Tese (Doutorado em Engenharia de Produção) Universidade Federal de Santa Catarina.

National Acadmy of Sciences/National Research Council (1993), Nutrients Requirements of fish. Washington, 102p.

Phadke, M. S. (1989), Quality engineering using robust design. Englewood Cliffs: PTR Prentice Hall, pp. 18-22.

Standard Methods - for the examination of water and wastewater. (1980), APHAAWWA-WPCF 1, 15 ed., pp. 380-491.
Stange, P. (1996), Sobre o gerenciamento da produção orientado para a qualidade total da empresa com base na função perda de Taguchi. Florianópolis: EPS/UFSC.

Taguchi, G., Elsayed, E. A. \& Hsiang, T. C. (1990), Engenharia da qualidade em sistemas de produção. São Paulo: Mc Graw - Hill, 235p

Wilson, R. P. (Ed.),, (1991), Handbook of nutrient requirements of finfish. Boca Raton: CRC, p.176.

Wu, V. Y.; Rosati, R. R.; Sessa, D. J. \& Brown, P. B. (1995b), Evaluation of corn gluten meal as a protein source in tilapia diets. J. Agric. Food Chem., 43, 1585-1588.

Received: July 23, 1998; Revised: December 28, 1998; Accepted: July 06, 1999. 